\title{
Profile and Professional Practices of Health Psychologists of the Federal District
}

\author{
Eliane Maria Fleury Seidl ${ }^{*}, 1$ \\ Orcid.org/0000-0002-1942-5100 \\ Sofia Costa e Silva Duarte ${ }^{2}$ \\ Orcid.org/0000-0001-7981-408X \\ Danielle Bernardes Magalhães ${ }^{1}$ \\ Orcid.org/0000-0001-9859-4115 \\ Marcela de Vasconcelos Costa ${ }^{1}$ \\ Orcid.org/0000-0001-8125-7913
}

${ }^{1}$ Universidade de Brasília, Brasilia, Distrito Federal, Brasil

${ }^{2}$ Hospital Santa Luzia, Brasília, Distrito Federal, Brasil

\begin{abstract}
The study aimed to describe the profile of psychologists from public and private health services of the Federal District, Brazil; to describe the professional practices, the theoretical-methodological frameworks adopted, expectations and perceptions of health work, as well as aspects that facilitate and hinder team integration. The instrument was a self-administered online questionnaire. The data analysis included descriptive and inferential statistical techniques and content analysis of the qualitative data. The participants were 96 psychologists (91.6\% women). The ages ranged from 24 to 54 years $(M=35.5)$ and the majority $(88.4 \%)$ were working in public health services. Individual psychological consultations and guidance for relatives/caregivers were the practices highlighted as being frequent in the professional quotidian. Diversified psychological practices were observed among the participants who were researchers, had graduate degrees and supervised undergraduate students and/or residents. Regarding aspects that facilitated team integration, the most frequent categories were: activities or care in multi/interdisciplinary team and regular team meetings. Regarding hindering aspects, work overload and personal and interpersonal characteristics of the professionals prevailed. The study highlights the strengthening of health psychology in the Federal District, especially in the services of the Brazilian National Health System, being incipient in private establishments.
\end{abstract}

Keywords: Health psychology, professional practices, interdisciplinary team.

* Mailing address: Universidade de Brasília, Instituto de Psicologia, Campus Universitário Darcy Ribeiro, Brasília, DF, Brazil, 70910-900. Phone: (061) 992111-087. E-mail: eliane.seidl@gmail.com

Financial support: National Council for Scientific and Technological Development (CNPq) through a research productivity grant for the first author. 


\section{Perfil e Práticas Profissionais de Psicólogos da Saúde do Distrito Federal}

\section{Resumo}

A pesquisa teve por objetivo descrever o perfil de psicólogos da rede pública e de serviços privados de saúde do Distrito Federal (DF), suas práticas profissionais, referenciais teórico-metodológicos adotados, expectativas e percepções do trabalho em saúde, bem como identificar aspectos que facilitam e que dificultam a integração da equipe. Foi aplicado um questionário online, disponibilizado na internet. A análise incluiu técnicas descritivas e inferenciais e de conteúdo para os dados qualitativos. Participaram 96 psicólogos, $91,6 \%$ mulheres. A idade variou de 24 a 54 anos $(M=35,5)$ e a maioria $(88,4 \%)$ atuava em serviço público de saúde. Sobre as práticas realizadas de forma frequente no cotidiano profissional, prevaleceu atendimento psicológico individual e orientação a familiares/cuidadores de pacientes. Práticas psicológicas diversificadas foram mais frequentes entre os participantes que tinham pós-graduação, realizavam pesquisa e faziam supervisão de estagiários de graduação e/ou residentes. Quanto aos aspectos facilitadores da integração da equipe, as categorias com maior ocorrência foram atividades ou atendimentos em equipe multi/interdisciplinar e reunião regular da equipe; quanto aos dificultadores prevaleceram as categorias sobrecarga de trabalho e caracteristicas pessoais e interpessoais dos profissionais. Resultados apontam o fortalecimento da psicologia da saúde no DF, especialmente no Sistema Único de Saúde, mostrando-se incipiente em estabelecimentos privados.

Palavras-chave: Psicologia da saúde, práticas profissionais, equipe interdisciplinar.

\section{Perfil y Prácticas Profesionales de Psicólogos de la Salud del Distrito Federal}

\section{Resumen}

El objetivo fue describir el perfil de psicólogos de los servicios públicos de salud y servicios privados del Distrito Federal; describir las prácticas profesionales, los referenciales teórico-metodológicos, expectativas y percepciones del trabajo en salud y aspectos facilitadores y dificultadores de la integración del equipo. El instrumento fue un cuestionario online. El análisis incluyeron técnicas estadísticas descriptivas y inferenciales y análisis del contenido para los datos cualitativos. Participaran 96 psicólogos, $91,6 \%$ mujeres. Edades oscilaban entre 24 a 54 años $(M=35,5)$ y la mayoría $(88,4 \%)$ trabajaba en servicio público de salud. A respeto de las prácticas realizadas frecuentemente en el trabajo diario, hubo énfasis en la atención psicológica individual y la orientación a familiares/cuidadores de pacientes. Prácticas psicológicas diversificadas fueran más frecuentes entre los participantes con posgrado, que realizaban investigaciones y hacían supervisiones de estudiantes de graduación y/o residentes. Acerca de los aspectos facilitadores de la integración del equipo, las categorias más frecuentes fueran actividades/ atendimientos en equipo multi/interdiciplinar y reunión regular del equipo; cuanto a los dificultadores, las categorías que prevalecieran fueran el sobrecargo de trabajo y características personales/interpersonales de los profesionales. El estudio evidencia el fortalecimiento de la psicología de la salud, especialmente en servicios del Sistema Único de Salud y se muestra incipiente en establecimientos privados.

Palabras clave: Psicología de la salud, prácticas profesionales, equipo interdisciplinario.

Health psychology, one of the fields of psychological science, has been expanding its sphere of action at the professional, teaching and research levels regarding subjects related to psychological aspects and the health-disease process. Advances in health psychology - in the context of psychological science and in relation to health sciences - have resulted from 
the strengthening and consolidation of the biopsychosocial concept in the comprehension and explanation of the processes of health maintenance, disease prevention, illness and death (Suls \& Rothman, 2004).

Several factors have been fundamental for the consolidation of health psychology, among which the following stand out: limitations of the biomedical model in the comprehension and explanation of the health-disease process; epidemiological changes and alterations in the morbidity and mortality profiles, with an increase in chronic-degenerative diseases, many of which are associated with behaviors and lifestyles; and the valorization of health promotion and disease prevention in the health policies of various countries (Straub, 2014). In the Brazilian context, the changes are more recent, both in the form of inclusion of psychologists into the health sector, and in the opening of new spaces of practice. It can be seen that the advent of the Brazilian Nation Health System (Sistema Único de Saúde - SUS), from the Health Reform movement and the promulgation of the Constitution in 1988, favored the growth and strengthening of psychology in the health area. The role of the SUS in this process must be highlighted, since its guiding principles - universality, integrality of care, equity and interdisciplinarity - favor the formation of multi and interdisciplinary teams, based on a comprehensive conceptualization of health and the valorization of the social determinants of the illness process, opposing the physician-centered model (Buss \& Pelegrini, 2007).

Brazilian studies with local characteristics have outlined the profile and practices of psychologists working in this field. In studies carried out in Florianópolis (Marcon, Luna, \& Lisbôa, 2004), the Federal District (Seidl \& Costa, 1999), and Natal (Yamamoto, Trindade, \& Oliveira; 2002) similarities were observed in aspects such as: a notable majority of female professionals; most of them with professional activities in a second area (practice in a private establishment); and greater inclusion in hospital units. Avellar (2011), researching psychology professionals in the hospitals of Greater Vitória/
ES, observed that the distribution was uneven, with a greater concentration in the capital, and that the traditional model of care predominated, based on the individual practice.

Expanding the focus for inclusion in other health units, a study, also with local characteristics, was conducted by Guimarães, Oliveira, and Yamamoto (2013), who interviewed six psychologists from mental health outpatient clinics in Aracaju/Sergipe, regarding their professional practices, working relationships with other specialists of the service and the impact produced by Outpatient Referrals in Mental Health on the health network flow chart. The predominance of traditional clinical work, few interdisciplinary actions, difficulty in articulation with the network, lack of knowledge about the work of the psychologist, lack of human resources and the hegemony of the biomedical model were reported as hindering aspects.

Due to the expansion of the inclusion of psychology in primary care in recent years, studies on the psychologist's work in this care level have increased, especially in the Family Health Strategy (FHS) and in Family Health Support Centers (FHSC). The FHS is focused on health promotion, care in the community and the guarantee of human rights; the priority of the FHSC is to provide a support matrix for the teams of the FHS, with the aim of increasing the quality and comprehensiveness of the primary care actions, considering the logic of territorialization (Oliveira et al., 2017). Interviewing 24 psychologists working in the FHSC from 16 health micro-regions in the state of Rio Grande do Norte, Oliveira et al. (2017) concluded that professionals often reproduced models of the traditional psychological practice, showing the work of the rest of the team to be fragmented and distant from the function of support for the matrix model. They also found that a lack of clarity prevailed over the role of psychology in the centers, despite the fact that the participants reflected on the practice of psychology and the need for models of performance different from the traditional ones.

The results of the study by Cela and Oliveira (2015) identified difficulties in establishing 
interdisciplinary relationships within the team and a lack of integration with the network. The low performance of the matrix support for the Family Health teams was also highlighted, even though this is the central axis of the action proposal of the FHSC.

In addition to studies that portrayed local realities, a national study (Spink, Bernardes, Santos, \& Gamba, 2007), for the Brazilian Association of Psychology Education (ABEP), based on information from the National Register of Health Establishments/DATASUS (http://cnes.datasus.gov.br), highlighted relevant aspects regarding the inclusion of psychologists in the SUS. At the beginning of 2006, records indicated the existence of 14,407 psychologists in health services linked to the SUS in the country, an indication that $6.55 \%$ of establishments had psychologists. A prominent result of the study revealed, however, that these were mainly included "in three types of care: $29.92 \%$ in Health Centers/Primary Health Units, $31.6 \%$ in outpatient units and hospitals (general and specialized) and $18.6 \%$ in mental health services (CAPS and psychiatric hospitals)" (p. 62), indicating that the percentage of professionals working in health centers and in primary care units, approached the number of those who worked in hospitals, indicating an important diversification of the inclusion of the psychologist in the SUS.

Another study at the national level was the investigation of the work of the psychologist that showed a modified panorama of the category in general and especially of psychology in the health field, highlighting that this area increased its number of professionals in a relevant way. Among the study respondents, more than 3,000 psychologists from the five Brazilian regions, the clinic was mentioned as the main area of practice - with $53.9 \%$ of the reports, followed by health in second place, with $27.0 \%$ (Gondim, Bastos, \& Peixoto, 2010).

Many of the studies cited were carried out ten or more years ago. In the last decade, there have been relevant changes in undergraduate courses in psychology, due to the reformulation of the curricular guidelines, giving great emphasis to the health area, with the intention to train psychologists so they are better prepared to work based on SUS guidelines (Resolução $n^{\circ} 5$, 2011). The issues presented allow for various plans to analyze the innovative ways that are being constructed in this field of action of the psychologist, which is still in the process of being discovered and consolidated. Thus, it is necessary to inform and educate the general public, managers and health professionals and the psychologists themselves - about the multiple and varied contributions they can make to the different levels of care in the health system, highlighting primary care (Furtado \& Carvalho, 2015; Polejack, Vaz, Gomes, \& Wichrowski, 2015; Thielke, Thompson, \& Stuart, 2011).

In the previous five years, there has been a significant increase in the number of psychologists that work in services in the Federal District (FD), as a result of public job selection processes carried out by the Federal District Health Department (SES-DF) and/or selection processes carried out in services, such as the University Hospital of Brasilia. From this perspective, the profile and practices of psychologists should be studied more, due to the opening of spaces originating from more recent SUS policies, such as the Family Health Support Centers (Portaria $n^{\circ} 154,2008$ ).

The following questions guided the present study: in which services, specialties and levels of care do the psychologists who work in the Federal District operate? How many are in public services and private services? What proportion of these have lato sensu specialization, Master's and/or Doctorate? What activities characterize their professional practice? Do the professional practices and the expectations and perceptions of healthcare differ according to the level of graduation or the length of time working in health? What aspects of the service facilitate or hinder teamwork, in the participants' perception?

These study questions allowed the objectives of the study to be outlined, which were as follows: 1. to describe the profile of psychologists who work in the public network and in private health services of the Federal District regarding sociodemographic aspects and 
professional training; 2 . to describe the levels of care, specialties and types of health services in which psychologists are included; 3. to identify the professional practices, the theoretical and methodological frameworks adopted, expectations and perceptions about the work in the health area and aspects of the integration of teamwork, based on the participants' reports; 4. to investigate associations of sociodemographic (age), training (graduate level training, or having taken a discipline or performed an internship in health in the undergraduate course) and health work (length of practice, performance of research or supervision) aspects with the variables expectations and perception of the work in health and forms of professional performance.

\section{Method}

\section{Participants}

The participants were 96 psychologists who worked in health in the Federal District, regardless of the type of employment contract. The inclusion criteria were: (a) to be hired for the position of psychologist, included in health teams to work with patients affected by various diseases for at least two months; and (b) to consent to participate in the study. The minimum period of two months was due to the professional's need to have some experience in the service(s) in order to respond to the study. It should be mentioned that only one participant had less than one year, totaling eight months of work.

Information obtained from the departments of human resources/people management of the main institutions of the SUS of the FD (SES-DF, University Hospital of Brasília, Sarah Network Brasília and Armed Forces Hospital) allowed the estimation that around 380 psychologists were working in health, when the data collection was carried out, leading to the conclusion that the number of participants needed was approximately $20 \%$ to $25 \%$ of the total. It was considered that this percentage would provide an overview of the professional reality of psychologists working in health institutions in the country's capital, even though the sample was by convenience.

\section{Instrument}

A self-administered questionnaire was designed for the study, with closed and open questions. A preliminary version of the instrument was submitted to the evaluation of two expert judges, professors and professionals in the health psychology field, who analyzed the adequacy of the instrument, considering the objectives of the study. The questionnaire was divided into sections to cover diverse information about the participants, namely: 1 . Socio-demographic data - gender, age, marital status, salary range and presence of children; 2. Professional training-public or private institution where undergraduate and graduate courses were attended; 3. Professional activities - information such as services and places of work, population served, theoretical-methodological framework adopted, length of working in health, forms of practice based on activities carried out in the professional routine; 4. Participation in scientific events, research and supervision - information on the participation of the professional in scientific events, performance of research and supervision in health; 5. Expectations and perceptions of the work in health - data on expectations and perception of the work, evaluated through 13 statements with a five-point Likert response scale ( $1=$ totally disagree, $5=$ totally agree), with a score obtained through the arithmetic mean, ranging from 1 (negative expectations and perceptions) to 5 (positive expectations and perceptions). Internal consistency analysis of this scale indicated a Cronbach's alpha of 0.72 , which is satisfactory; 6 . Perception of teamwork - open question reports including up to three aspects present in the institution and/or in the workplace that facilitate or hinder the integration of the team.

\section{Data Collection Procedures}

The project was submitted and approved by the Research Ethics Committee of the Institute of Human Sciences of the University of Brasilia (Authorization No. 974838).

The data were collected through an online survey, made available to participants for three months, by inserting the instrument into the 
Survey Monkey platform. An email database of health psychologists, working in public or private services, was constructed from institutional contacts. Each psychologist invited was asked to send the invitation email received, with the link to access the research site and to disseminate the study within their professional networks, based on the strategy called snowball sampling, which provides a non-probabilistic sample through reference chains, useful for social groups with some dispersion that hinders access to the participants (Vinnuto, 2014). The consent form was on the main page of the site, containing the presentation of the study and highlighting the confidentiality and anonymity of the participants. When agreeing to participate, the participant needed to click on "continue" at the bottom of the page, expressing their consent, with the option to print the consent form.

\section{Data Analysis Procedures}

Procedures for the descriptive statistical analysis were carried out using the SPSS software (Statistical Package for the Social Sciences), version 20 for Windows. Then, measures of association, such as the chisquare test, Pearson's correlation and Student's $t$-test, were performed, aiming to identify the magnitude and nature of the relationships between the study variables. Regarding the instrument that dealt with expectations and perceptions of the work in health, the data were submitted to internal consistency analysis (Cronbach's alpha $=0.72$ ). This procedure was followed by other statistical analyses. The level of significance was $p \leq .05$. For the analysis of the answers to the open questions, content analysis procedures were used, from Bardin's perspective (2011), which initially included the free-floating reading of the material. There was no prior categorization, and the categories were identified retrospectively after the corpus was analysis by two independent researchers, based on the agreement of their analyses (minimum of $80 \%$ ) for the identification, naming and frequency of the categories; excerpts from the reports were selected to illustrate them.

\section{Results}

\section{Sociodemographic Characterization}

A total of 96 psychologists participated, of whom $91.6 \%$ ( $n=87)$ were women and $8.4 \%$ $(n=8)$ men; one participant did not report the gender. The age ranged from 24 to 54 years $(M=35.5 ; S D=6.6 ; \quad M d=34)$. Concerning the marital status, the majority $(58.9 \% ; n=56)$ reported being married or in a stable union, with $29.5 \%(n=28)$ of the professionals being single. The psychologists who reported having children constituted $42.1 \%(n=40)$ of the participants. With regard to the gross salary range, due to the employment relationship in the health area, $34.7 \%(n=33)$ reported receiving between four and six minimum salaries (MS); $17.9 \%(n=17)$ reported from 7 to $9 \mathrm{MS}, 26.3 \%(n=25)$ reported the range from 10 to $13 \mathrm{MS}$ and $16.8 \%(n=14)$ reported wages equal to or greater than $14 \mathrm{MS}$. Four participants (4.2\%) reported the range from 0 to $3 \mathrm{MS}$. Chi-square tests revealed that higher salaries (from $7 \mathrm{MS}$ ) were significantly associated with a stricto sensu graduation course, working in the SUS, weekly workload of 40 hours and length of service of more than 10 years.

\section{Training}

Of the total number of participants, $59.4 \%(n=57)$ reported having completed the undergraduate course in a private educational institution; $68.8 \% \quad(n=66)$ graduated in the Federal District, while 31.3\% $(n=30)$ did their course in another city of the country. Almost $70 \%$ of the professionals $(69.8 \% ; n=67)$ reported having taken undergraduate disciplines in Health Psychology, however $30.2 \%(n=29)$ reported not having taken one or did not respond. Half of the professionals $(50 \% ; n=48)$ reported having performed a supervised health internship at the undergraduate level and the other half did not report having performed this internship.

Regarding the lato sensu graduate course in Health and/or Hospital Psychology, 32.3\% $(n=31)$ reported having the specialization and $3.1 \%$ were studying for it $(n=3)$. A total of 12 
psychologists (12.5\%) reported having the title of specialist conferred by the Regional Psychology Councils. Approximately one third (34.4\%; $n=33$ ) reported having a Master's degree and $6.3 \%(n=6)$ a Doctoral degree, with 9.4\% studying for a Master's $(n=9)$ and $2.1 \%$ $(n=2)$ for a Doctorate.

\section{Professional Work in Health}

Regarding the professional work, the majority $(88.4 \% ; n=84)$ reported working in a public service, and $84.4 \%(n=81)$ were contracted through a public job selection process. Many of the participants $(71.6 \% ; n=68)$ reported working in the institution for a period ranging from less than one year to six years. The workload reported was distributed between 20 hours $(33.3 \% ; n=32), 30$ hours $(11.5 \% ; n=11)$ and 40 hours $(52.1 \% ; n=50)$ per week. The length of time working in health was also asked about, considering internships in the area, other jobs and the current employment. The mean time was 8.6 years $(S D=6.02, M d=7.0$, minimum $=8$ months, maximum $=28$ years).

Regarding the exercise of other professional activities in psychology, the sample was divided: $48.4 \% \quad(n=46) \quad$ reported performing other activities and $51.6 \%(n=49)$ did not. Among those who performed other activities outside the health field $(n=46), 35$ were working in practice and 11 referred to teaching. With regard to the type of health service(s) in which they worked (they could report more than one alternative), $64(66.7 \%)$ of the participants mentioned the hospital, 7 (7.3\%) mentioned the health center and $10(9.6 \%)$ reported that they worked in a psychosocial care center (CAPS), with 8 in CAPS mental disorders and two in CAPS alcohol and drugs. The Family Health Strategy was marked by two professionals $(2.1 \%)$ and 10 $(9.6 \%)$ of them marked the 'other' alternative. When asked to indicate in which site(s) of the health units they worked (they could indicate more than one alternative), the majority of the professionals $(n=63)$ reported working in an outpatient clinic of a hospital unit, 47 reported working on a ward, 24 reported an ICU, 10 the emergency room/emergency unit, 10 reported that they worked in a Psychosocial Care Center (CAPS), two referred to the Family Health Strategy (FHS) and 5 mentioned home care.

Through an open question, it was asked which specialty(s) they practiced at the time of the study. The reports were categorized and the frequencies were identified, showing a great diversity of specialties: pediatrics $(n=21)$, neurology/neurosurgery $(n=12)$, oncology $(n=10)$, medical/general clinical $(n=10)$, neonatology/ pediatric and neonatal ICU $(n=9)$, gynecology/ obstetrics/high risk pregnancy $(n=8)$, mental health/mental disorders $(n=8)$, adult ICU $(n=6)$, alcohol and drugs $(n=4)$, HIV/aids $(n=4)$ and orthopedics $(n=4)$. Another 17 areas were cited, ranging from 1 to 3 occurrences. Regarding the types of users with whom they worked, with the possibility of marking more than one alternative, $80.2 \%(n=77)$ of the respondents indicated adults and $78.1 \%(n=75)$ indicated family members and caregivers of patients. Working with adolescents was reported by $53.1 \%(n=51)$, older adults by $55.2 \%(n=53)$ and children by $47.9 \%(n=46)$ of the participants. A total of $13(13.5 \%)$ answered that they also worked with other types of patient, such as health providers/staff and babies.

When asked about which theoreticalmethodological framework(s) guided their professional practice (they could mark more than one alternative) they reported: cognitivebehavioral $(n=41 ; 42.7 \%), \quad$ psychoanalysis ( $n=28 ; 29.2 \%)$, humanist-existentialist $(n=22$; $22.9 \%)$, behavioral $(n=16 ; 16.7 \%)$, systemic $(n=16 ; 16.7 \%)$, gestalt, $(n=14 ; 14.6 \%)$, sociohistorical $(n=13 ; 13.5 \%)$, psychodrama $(n=9$; $9.4 \%)$ and cognitive $(n=6 ; 6.2 \%)$. The option 'others' was included in this question, allowing frameworks not mentioned in the closed alternatives to be reported. Social psychology $(n=2 ; 2.1 \%)$, collective health $(n=1 ; 1.0 \%)$, amplified clinic $(n=1 ; 1.0 \%) ;$ psychosocial approach $(n=1 ; 1.0 \%)$ and schizoanalysis $(n=1$; $1.0 \%)$ were cited. The majority $(55.2 \% ; n=53)$ indicated one theoretical-methodological orientation, $26.0 \%(n=25)$ mentioned two and $11.5 \%(n=11)$ mentioned guiding themselves using three frameworks in their professional practice. 
Participation in Scientific Events, Performance of Research and Supervision Activities

Regarding the participation in scientific events (congresses, seminars, etc.), the majority $(63.5 \% ; n=61)$ reported attending frequently (annually/every two years) and 19.8\% $(n=19)$ reported participating (every three to four years). Among those who reported going to these events, $80 \%(n=76)$ reported attending as participants, without presenting work, with oral or poster communications. Regarding the performance of research in the previous five years, $61.5 \%$ $(n=59)$ reported not performing this work. Regarding supervising undergraduate students and/or residents, $44.8 \%(n=43)$ reported not having exercised this activity. However, $61.5 \%$ $(n=59)$ reported that they were performing and/or had already performed supervisory/ preceptorship activities at the undergraduate level, for psychology residents or those of other areas (medicine), as well as for professionals on training or specialization courses.

\section{Practices Performed in the Professional Quotidian}

Considering the practices carried out frequently or occasionally in the professional quotidian, Figure 1 presents the distribution of these performed frequently, occasionally and not performed. The most frequent practices cited were: individual psychological care $(n=87$; $93 \%$ ), guidance to family members/caregivers of patients $(n=81 ; 87 \%)$, psychological care to family members/caregivers $(n=65 ; 69 \%)$, health education activities $(n=55 ; 59 \%)$ and care/interventions in a group of patients $(n=51$; $55 \%)$. There was a low frequency of the use of standardized tests and scales, with $52 \%$ of the psychologists saying they did not use these types of instruments and $25 \%$ mentioning occasional use.

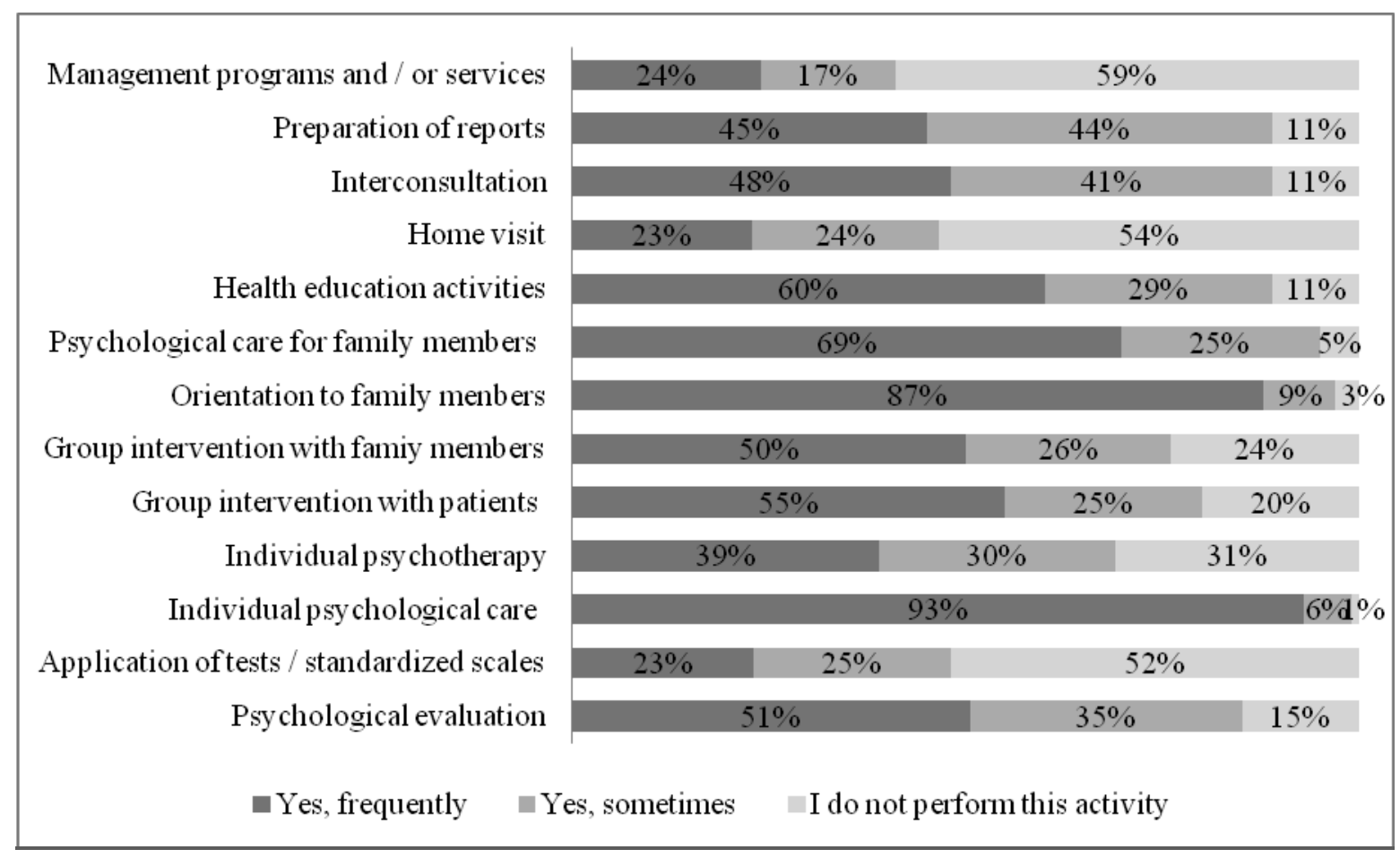

Figure 1. Professional practices performed, according to reports of the participants.

It was considered that the performance of a greater diversity of procedures and psychological techniques could represent more extensive ways of working, compatible with the different health requirements. Thus, it was chosen to integrate the information of this variable, composing a score from the following points: frequent performance (two points); occasional performance (one point); no performance (zero points). Based on the records of the practices performed, a score 
was calculated for each participant, transforming this into a continuous variable that ranged from zero to 26 . The mean score of the sample was $16.43(S D=4.03 ; M d=17.0$, minimum=3, maximum $=26$ ). The analysis of the normality of the distribution of this variable indicated that it was not violated, based on the KolmogorovSmirnov test $(K S=1.06 ; p=.21)$.

\section{Perceptions and Expectations regarding the Work of the Psychologist in Health}

This variable was evaluated through thirteen items that investigated perceptions and expectations about the work of the psychologist in health. A total of 93 participants answered, with the mean score obtained being $3.77(S D=0.51$, $M d=3.85, \quad$ minimum $=2.23$, maximum $=4.77$ ), indicating that there was variability in the responses, revealing professionals with positive expectations and perceptions about the work and others with unfavorable expectations and views. The distribution of this variable regarding the normality was also investigated, with there being no violation of this assumption, according to the Kolmogorov-Smirnov test $(K S=0.78 ; p=0.57)$.

Table 1 shows the distribution of responses to the thirteen items, grouped into three levels: tendency to agree, midpoint and tendency to disagree. There was a tendency to agree with many of the statements, with emphasis on the interest in continuing to work in the health area, which accounted for $85 \%$ of the responses. A high percentage of disagreement (29.7\%) was observed in the item that indicated that the professionals with whom the psychologists worked were an interdisciplinary team, as well as in the item that mentioned communication among the professionals $(25.8 \%)$. These results show challenges in the context of relationships and communication among the team members, from the perspective of the participants. The statement that "the thing that most contributed to my choice of the health psychology area was the labor market opportunities" had the highest percentage of disagreement (44.1\%), indicating that it was not the possibilities of the market that led to choosing the work, but personal interests and choices.

\section{Associations between Study Variables}

As the two variables of interest - perceptions and expectations about work in health and forms of professional performance - did not violate assumptions about normality, the subsequent bivariate analyses were performed using parametric tests. Regarding the perceptions and expectations about the work, the results of Student's $t$-test showed that having attended an undergraduate health psychology discipline was associated with higher scores in this variable, with a statistically significant difference, while the other variables studied did not distinguished the two groups (Table 2). Regarding the forms of professional practice variable, higher mean scores, with statistically significant differences, were observed for professionals who had graduate degrees, performed research or supervised trainees and/or residents (Table 2). Having attended a health discipline and/or internship during the undergraduate course did not differentiate between those who reported a higher or lower diversity of professional practices.

In the Pearson's correlation analyses, perceptions and expectations about work in health did not correlate with age $(r=-0.02 ; p=.83)$, length of time working in health $(r=0.09 ; p=.39)$, nor with forms of professional practice $(r=0.14$; $p=.19$ ). The correlation coefficient showed significant negative and moderate associations with age $(r=-0.26 ; p=.01)$ and length of time working in health $(r=0.27 ; p=.007)$, indicating that older and more mature professionals performed a more diversified practice, using different techniques and procedures.

\section{Aspects that Facilitate and Hamper the Teamwork}

The participants were asked to report up to three aspects that facilitated the integration of the health team. Table 3 presents the seven most frequent categories.

Other less frequent categories were: management that favored team integration $(n=13)$; recognition of the psychologist's work $(n=12)$; horizontality/respect/trust in the 
Table 1

Expectations and Perceptions of Psychology Work in the Health Area $(n=93)$

\begin{tabular}{|c|c|c|c|}
\hline Items of the scale & $\begin{array}{c}\text { Tendency } \\
\text { to disagree } \\
F(\%)\end{array}$ & $\begin{array}{c}\text { Neither agree } \\
\text { nor disagree } \\
F(\%)\end{array}$ & $\begin{array}{c}\text { Tendency } \\
\text { to agree } \\
F(\%)\end{array}$ \\
\hline $\begin{array}{l}\text { Health is my area of interest since the graduation } \\
\text { course }\end{array}$ & $14(15.1)$ & $18(19.4)$ & $61(65.6)$ \\
\hline I am interested in continuing to work in the field of health psychology & $3(3.2)$ & $11(11.8)$ & $79(85.0)$ \\
\hline $\begin{array}{l}\text { What most contributed to my choice of the area of health psychology } \\
\text { were my personal expectations }\end{array}$ & $20(21.5)$ & $25(26.5)$ & $48(51.6)$ \\
\hline $\begin{array}{l}\text { There is compatibility between my expectations about the performance } \\
\text { of the psychologist in the area of health and the activities that I perform }\end{array}$ & $9(9.7)$ & $9(9.7)$ & $75(80.7)$ \\
\hline $\begin{array}{l}\text { I feel the need for specific training to improve my professional } \\
\text { performance in the area }{ }^{1}\end{array}$ & $10(11.0)$ & $4(4.4)$ & $77(84.7)$ \\
\hline My work is carried out in a multidisciplinary team & $8(8.7)$ & $9(9.7)$ & $76(81.7)$ \\
\hline $\begin{array}{l}\text { What most contributed to my choice of the area of health psychology } \\
\text { were the labor market opportunities }{ }^{2}\end{array}$ & $41(44.1)$ & $20(21.5)$ & $32(24.4)$ \\
\hline The professionals with whom I work constitute an interdisciplinary team ${ }^{1}$ & $27(29.7)$ & $9(9.9)$ & $55(60.5)$ \\
\hline $\begin{array}{l}\text { My work as a psychologist is recognized by the health team } \\
\text { with which I work }\end{array}$ & $6(6.5)$ & $12(12.9)$ & $75(80.7)$ \\
\hline We usually discuss our performance in team meetings & $20(21.6)$ & $18(19.4)$ & $55(59.1)$ \\
\hline I am satisfied with my professional work in health psychology & $13(14.0)$ & $17(18.3)$ & $63(67.8)$ \\
\hline $\begin{array}{l}\text { The communication between the professionals of the team } \\
\text { where I work is carried out in a clear and objective way }\end{array}$ & $24(25.8)$ & $19(20.4)$ & $50(53.8)$ \\
\hline In my training, I felt a lack of training more targeted toward teamwork & $22(23.7)$ & $9(9.7)$ & $62(66.7)$ \\
\hline
\end{tabular}

Note. ${ }^{1}$ five missing data in this item; ${ }^{2}$ item recoded in the composition of the mean score.

professional relationships $(n=10)$; personal characteristics of the professionals $(n=10)$; training and technical-scientific updates $(n=7)$; autonomy and freedom to take decisions $(n=7)$; compatible working hours $(n=6)$; qualification of the professionals $(n=5)$; length of working in the service $(n=5)$.

Regarding the aspects that hampered the integration of the team, the most frequent categories and their respective illustrative examples are presented in Table 4. Other categories identified in the responses of the participants were: human resources shortages ( $n=13)$; lack of training/continuing education $(n=12) ; \quad$ management problems/limitations $(n=10)$; stress/burnout $(n=8)$; conflicts between professionals $(n=4)$; training that does not support interdisciplinary work $(n=1)$ and characteristics of the work process $(n=38)$. This category was divided into subcategories, such as: incompatibility of hours/shifts $(n=13)$; requirement for productivity statistics $(n=9)$; bureaucracy $(n=4)$; precariousness of the work $(n=3)$; lack of interdisciplinary procedures $(n=3)$; staff turnover $(n=2)$; fragmentation of the work $(n=2)$ and low remuneration $(n=2)$.

Finally, the positive evaluation that the psychologists gave regarding the participation in the study should be mentioned: of the 96 professionals, 75 responded to this question. The initiative, the instrument, the relevance and clarity of the questions were commended. The 
Table 2

Mean Scores and Student's T-Test Results regarding Expectations and Perception of Health Work and Forms of Professional Performance, according to the Study Variables

\begin{tabular}{|c|c|c|c|c|}
\hline \multicolumn{2}{|c|}{ Expectations and perception of the work in health ${ }^{1}$} & $M$ & $S D$ & $t$ \\
\hline \multirow[b]{2}{*}{ Training } & Undergraduate degree & 3.66 & 0.49 & \multirow[b]{2}{*}{-1.38} \\
\hline & Lato and/or stricto sensu graduate degree & 3.81 & 0.51 & \\
\hline \multirow{2}{*}{$\begin{array}{l}\text { Attended discipline } \\
\text { of Health Psychology }\end{array}$} & Yes & 3.87 & 0.42 & \multirow{2}{*}{$2.37 *$} \\
\hline & No & 3.55 & 0.63 & \\
\hline \multirow{2}{*}{$\begin{array}{l}\text { Internship in Health } \\
\text { Psychology }\end{array}$} & Yes & 3.87 & 0.51 & \multirow{2}{*}{1.92} \\
\hline & No & 3.67 & 0.49 & \\
\hline \multirow{2}{*}{$\begin{array}{l}\text { Conducted research } \\
\text { (previous } 5 \text { years) }\end{array}$} & Yes & 3.90 & 0.56 & \multirow{2}{*}{1.82} \\
\hline & No & 3.70 & 0.46 & \\
\hline \multirow{2}{*}{$\begin{array}{l}\text { Performance of supervision } \\
\text { (current or previous) }\end{array}$} & Yes & 3.85 & 0.49 & \multirow{2}{*}{-1.66} \\
\hline & No & 3.67 & 0.52 & \\
\hline & ns of professional performance ${ }^{2}$ & $M$ & $S D$ & $t$ \\
\hline \multirow{2}{*}{ Training } & Undergraduate degree & 14.60 & 4.56 & \multirow{2}{*}{$2.82 * *$} \\
\hline & Lato and/or stricto sensu graduate degree & 17.26 & 3.57 & \\
\hline \multirow{2}{*}{$\begin{array}{l}\text { Attended discipline } \\
\text { of Health Psychology }\end{array}$} & Yes & 16.39 & 3.70 & \multirow{2}{*}{0.17} \\
\hline & No & 16.58 & 5.17 & \\
\hline \multirow{2}{*}{$\begin{array}{l}\text { Internship in Health } \\
\text { Psychology }\end{array}$} & Yes & 16.92 & 3.79 & \multirow{2}{*}{1.18} \\
\hline & No & 15.94 & 4.32 & \\
\hline \multirow{2}{*}{$\begin{array}{l}\text { Conducted research } \\
\text { (previous } 5 \text { years) }\end{array}$} & Yes & 18.65 & 3.60 & \multirow{2}{*}{$4.71 * * *$} \\
\hline & No & 15.03 & 3.75 & \\
\hline \multirow{2}{*}{$\begin{array}{l}\text { Performance of supervision } \\
\text { (current or previous) }\end{array}$} & Yes & 17.33 & 3.36 & \multirow{2}{*}{$2.44 *$} \\
\hline & No & 15.23 & 4.63 & \\
\hline
\end{tabular}

Note. ${ }^{1}$ Score obtained through the arithmetic mean of the five point Likert scale responses to 13 statements, ranging from 1 (negative expectations and perceptions) to 5 (positive expectations and perceptions). ${ }^{2}$ Based on the reports regarding the practices performed, the score ranged from 0 to 26: with higher scores equating to the greater diversity of practices performed. $* p \leq .05 ; * * p \leq .01 ; * * * p \leq .001$.

participants reported that the study provided analyses of the practice itself, given the scarcity of time for reflections about the work quotidian. The reports mentioned the interest in knowing the results and the expectation that the study could help in the improvement of the continuous education of SUS psychologists of the FD.

\section{Discussion}

The sociodemographic characterization revealed the predominance of women professionals, young people, with a relatively short time working in the area, working in SUS public services for 40 hours a week and with 
Table 3

Most Frequent Categories of Aspects that Facilitate Team Integration

\begin{tabular}{|c|c|c|}
\hline Categories & $F$ & Examples of reports \\
\hline $\begin{array}{l}\text { Multi or interdisciplinary } \\
\text { team activities or care }\end{array}$ & 36 & $\begin{array}{l}\text { Multidisciplinary care; Existence of FHS in the Health Center where } \\
\text { cases often require integrated action; The rounds in the wards and ICUS } \\
\text { allow direct and frequent contact with other professionals. }\end{array}$ \\
\hline Regular team meeting & 34 & $\begin{array}{l}\text { Implementation of monthly meeting of the psychology team ...; Technical } \\
\text { meeting with the presence of everyone. }\end{array}$ \\
\hline $\begin{array}{l}\text { Ease of communication } \\
\text { and relationships }\end{array}$ & 27 & $\begin{array}{l}\text { Openness to communication among the professionals; Exchanges of } \\
\text { information with another psychologist of the service; Respect among } \\
\text { colleagues. }\end{array}$ \\
\hline $\begin{array}{l}\text { Interest and integrative } \\
\text { attitude of psychologists } \\
\text { and team professionals }\end{array}$ & 22 & $\begin{array}{l}\text { The desire of the psychologist to be part of the team; Enjoying what is } \\
\text { done; Commitment to the work proposal; Involvement of everyone with } \\
\text { a cause that everyone thinks is important. }\end{array}$ \\
\hline Discussion of cases & 18 & $\begin{array}{l}\text { Discussion of cases and conduct; The psychology team has monthly } \\
\text { meeting to discuss conducts, development in medical records and } \\
\text { doubts; The workload is similar and there are a lot of meetings to } \\
\text { discuss cases, as well as outside the meeting. }\end{array}$ \\
\hline $\begin{array}{l}\text { Paradigm and ideology } \\
\text { of humanization/ } \\
\text { biopsychosocial concept }\end{array}$ & 15 & $\begin{array}{l}\text { Ideology of humanization in health; Consideration of subjectivity by the } \\
\text { majority of the team; Biopsychosocial view of the patient. }\end{array}$ \\
\hline $\begin{array}{l}\text { Improvement and sharing } \\
\text { of physical space }\end{array}$ & 14 & $\begin{array}{l}\text { Physical proximity among the members of the team (most of the } \\
\text { professionals dedicate all of their hours to working in the unit, remaining } \\
\text { in the place most of the time); Adequate space for care ...; Shared room. }\end{array}$ \\
\hline
\end{tabular}

relatively modest salary ranges, results that are in line with other studies which identified similar profiles (Gondim et al., 2010; Seidl \& Costa, 1999; Spink et al., 2007). With regard to training, the majority of the psychologists had graduate degrees, both lato and stricto sensu, indicators of seeking professional qualification in the sample studied. Concerning the performance in other areas, almost half said that they carried out other activities, with many working in practice, giving consultations, results also evidenced in the studies of Gondim et al. (2010) and Seidl and Costa (1999). This reality seems to be due to the need to supplement the income -in view of the wages earned, in addition to the fact that many worked 20 or 30 hours per week, favoring the performance of another paid activity.

Regarding the inclusion in health services, there was still a greater concentration in hospital units (wards, outpatient clinics, ICUs and emergency services), however, greater diversification can be observed, given the comparison with results of another study carried out in the country's capital (Seidl \& Costa, 1999). This was because a greater presence of professionals was identified in CAPS (mental health, alcohol and drugs) and in health centers. The low number of psychologists participating in the FHS should be highlighted, a result that is a reflection of the reduced inclusion of the psychologist in this FD program, resulting from the public health policies of the FD Health Department. Studies have highlighted the role that psychology can play in primary healthcare, by developing health promotion and disease prevention activities, many of which are community based (Leite, Andrade, \& Bosi, 2013; Polejack, Gomes, Miranda, \& Machado, 2015). This has still been little explored in the SUS of the FD, given the limited inclusion of this professional in the FHS and FHSC, for example. This reality needs further studies, possibly of 
Table 4

Most Frequent Categories of Aspects that Hinder Team Integration

\begin{tabular}{|c|c|c|}
\hline Categories & $F$ & Examples of reports \\
\hline Work overload & 27 & Work overload; Lack of time due to high patient demand; Excess of work. \\
\hline $\begin{array}{l}\text { Personal and interpersonal } \\
\text { characteristics of the } \\
\text { professionals }\end{array}$ & 24 & $\begin{array}{l}\text { Interpersonal problems of some team members; Personal intrigues; } \\
\text { Individualism; Presumption; Demotivation. }\end{array}$ \\
\hline $\begin{array}{l}\text { Ideologies/attitudes } \\
\text { of the biomedical model }\end{array}$ & 19 & $\begin{array}{l}\text { The biomedical model is still very ingrained in the hospital environment; } \\
\text { Tradition of the institution and the SES still physician-centered; } \\
\text { Professional training that privileges medical knowledge to the detriment } \\
\text { of other professionals of the health area. }\end{array}$ \\
\hline Communication difficulties & 17 & $\begin{array}{l}\text { Professionals without adequate training for team communication; Entry } \\
\text { of medical professionals with difficulty of communication with patients; } \\
\text { Communication between professionals in different areas is inefficient ..., } \\
\text { which does not allow the identification of the patient's requirements and } \\
\text { joint intervention. }\end{array}$ \\
\hline $\begin{array}{c}\text { Inadequacy/insufficiency } \\
\text { of physical space } \\
\text { and material resources }\end{array}$ & 16 & $\begin{array}{l}\text { Lack of material resources and psychological tests; Lack of physical } \\
\text { space; Physical space shared with other services; Space not appropriate. }\end{array}$ \\
\hline $\begin{array}{l}\text { No knowledge/no recognition } \\
\text { of the psychologist's work }\end{array}$ & 15 & $\begin{array}{l}\text { No knowledge of the attributions of psychology; Difficulty of the medical } \\
\text { team in complying with the opinion of the psychologist; Request for a } \\
\text { psychologist only for intervention in crisis; Not reading the contents of } \\
\text { psychology. }\end{array}$ \\
\hline $\begin{array}{l}\text { Failures in interdisciplinary } \\
\text { articulation }\end{array}$ & 14 & $\begin{array}{l}\text { Academic training that does not establish academic knowledge and } \\
\text { practices focused on Public Health in the scope of interdisciplinarity; } \\
\text { Need to change from multidisciplinary to interdisciplinary; Inexistence of } \\
\text { clinical team meetings to plan and integrate their activities. }\end{array}$ \\
\hline
\end{tabular}

a qualitative nature, to better comprehend the problem.

The results indicated that the participants mostly had positive expectations and perceptions about the work in health, however, there was variability in the answers, with some professionals presenting positive expectations and perceptions and others unfavorable expectations and views. It should be mentioned that the great majority expressed satisfaction with the work, felt recognized and evaluated that there was compatibility between the expectations about the performance of the health psychologist and the activities that were carried out. The items of which the responses indicated greater dissatisfaction were those that addressed communication processes and the team's interdisciplinary performance, a result that was consonant with the qualitative data, since the categories of as- pects perceived to hinder team integration included: communication difficulties and failures in the interdisciplinary articulation. On the other hand, the facilitator aspects cited, with a greater number of reports, were: activities or care in the multi/interdisciplinary team, regular meetings of the team, and ease in communication and relationships. Interdisciplinary action is still a challenge, as indicated in other studies (Cela \& Oliveira, 2015; Guimarães et al., 2013).

As seen in the study by Couto, Schimith, and Dallbelo-Araújo (2013), it is necessary for the role of the psychologist to be clear for the health teams and for the population, so that this professional can participate effectively in interdisciplinary actions. These authors observed that the incompatibility of schedules can be an obstacle to the establishment of interdisciplinary practices, as well as the 
overlap of one specialty with another due to the organizational culture still being hierarchical and often based on the biomedical concept, which hinders communication within the team. Other categories identified as hindering the integration of the team confirm the position of these authors: no knowledge/no recognition of the work of the psychologist and characteristics of the work process. The presence of biomedical concepts was also highlighted in the participants' reports: the ideology/attitudes of the biomedical model category emerged with high frequency as an aspect that makes integration difficult, a struggle that still has to be waged in the quotidian of many teams.

Regarding the forms of professional performance, the strong predominance of individual practices carried out in a frequent or occasional way was evidenced, directed toward patients and their families, a fact observed by other researchers (Avellar, 2011; Oliveira et al., 2017). The transformation of the forms of professional performance into a continuous variable aimed to differentiate the participants regarding those who performed their practice in a more diversified or restricted way, taking into consideration the frequency with which they performed the actions. It was considered that the execution of a greater diversity of interventions and psychological techniques could represent more extensive forms of practice, in conformity with the diversity of the psychological and psychosocial requirements in health, from the perspective of interdisciplinarity, integral and equitable care (Rudnicki \& Sanches, 2014; Seidl \& Miyazaki, 2014). Although a tendency towards diversification was observed, the results of the present study are insufficient to conclude that the traditional clinical model does not prevail in the forms of practice mentioned by the participants. It may be that the data collection strategy regarding this variable (responses given to closed alternatives) limited the information about the practices performed. It is recommended that in future studies other qualitative methodological strategies are applied, given the complexity that characterizes studies on practices and forms of professional performance.
Regarding the scarce application of scales and standardized tests, since the majority reported not using them, this data may represent a lack of knowledge of the potential of these instruments as technical resources complementary to the evaluation process, for example. Standardized psychometric instruments can be classified as psychological and/or psychosocial as well as being valid for evaluating interventions, supporting the paradigm of evidence-based practices (Rousseau \& Gunia, 2016). Activities of management of programs and/or services were reported by approximately a quarter of the participants, indicating the greater presence of psychologists in managerial levels of the Federal District's SUS and the in the consolidation of public health policies. This data, although promising, does not allow the conclusion that the inclusion of psychology professionals at the managerial level can favor paradigm changes in the care and/or managerial fields, with other studies being necessary to deepen this possible influence and/or association.

Another result to be highlighted was the differentiation of the forms of professional performance: graduate level training, conducting research and supervision (i.e., carrying out teaching and training activities) being associated with a more diversified practice. Regarding supervision and preceptorship, it is considered that these teaching actions can lead to the need for updating and continuous and permanent education, with possibilities of positive repercussions in the forms of professional performance.

The data also revealed the diversity of theoretical and methodological references that guide the professional practice, with the cognitive-behavioral approach predominating as a single approach, followed by psychoanalysis, with $26 \%$ mentioning the use of two and $11.5 \%$ mentioning the use of three methodological frameworks in their professional practice. The association of frameworks was also evidenced by Gondim et al. (2010) when they observed that $27 \%$ of the health psychologists indicated that they combined more than three approaches and $23 \%$ more than two. This is a current reality of 
the profession that requires further studies and investigations, as suggested by Gondim et al. (2010).

It was concluded that the study achieved its objectives and may have relevant practical implications, especially in the articulation of the university with health policies and services of the public and private spheres, for training and advances in the professional qualification. With regard to the data collection strategy, the online research allowed greater accessibility to the population of health psychologists, given the dispersion of the category that generally has few professionals in the various services. Considering the limitations, the fact that the sample was by convenience always restricts any generalizations of the results. The results also indicated important advances in strengthening and consolidating health psychology as a professional field in the Federal District and could assist managers in the identification of shortages of psychology professionals in different areas of the system, allowing adjustments, considering the quality, interdisciplinarity and integrality of the healthcare in the country's capital.

\section{Authors' Contributions}

Substantial contribution in the concept and design of the study: Eliane Maria Fleury Seidl.

Contribution to data collection: Eliane Maria Fleury Seidl, Sofia Costa e Silva Duarte, Danielle Bernardes Magalhães e Marcela de Vasconcelos Costa.

Contribution to data analysis and interpretation: Eliane Maria Fleury Seidl, Sofia Costa e Silva Duarte, Danielle Bernardes Magalhães e Marcela de Vasconcelos Costa.

Contribution to manuscript preparation: Eliane Maria Fleury Seidl.

Contribution to critical revision, adding intelectual content: Eliane Maria Fleury Seidl, Sofia Costa e Silva Duarte, Danielle Bernardes Magalhães e Marcela de Vasconcelos Costa.

\section{Conflicts of interest}

The authors declare that they have no conflict of interest related to the publication of this manuscript.

\section{References}

Avellar, L. Z. (2011). Atuação do psicólogo nos hospitais da grande Vitória/ES: Uma descrição. Psicologia em Estudo, 16(3), 491-499. doi: 10.1590/S1413-73722011000300016

Bardin, L. (2011). Análise de conteúdo. Lisboa: Edições 70.

Buss, P. M., \& Pellegrini, A., Filho. (2007). A saúde e seus determinantes sociais. Physis: Revista de Saúde Coletiva, 17(1), 77-93.

Cela, M., \& Oliveira, I. F. (2015). O psicólogo no Núcleo de Apoio à Saúde da Família: Articulação de saberes e ações. Estudos de Psicologia (Natal), 20, 31-39. doi: 10.5935/1678-4669.20150005

Couto, L., Schimith, P., \& Dalbello-Araujo, M. (2013). Psicologia em ação no SUS: A interdisciplinaridade posta à prova. Psicologia: Ciência e Profissão, 33(2), 500-511. doi: 10.1590/ S1414-98932013000200018

Furtado, M. E. M. F., \& Carvalho, L. (2015). O psicólogo no NASF: Potencialidades e desafios de um profissional de referência. Revista Psicologia e Saúde, 7(1), 9-17.

Gondim, S. M. G., Bastos, A. V. B., \& Peixoto, L. S. A. (2010). Áreas de atuação, atividades e abordagens teóricas do psicólogo brasileiro. In A. V. B. Bastos, S. M. G. Gondim, \& colaboradores (Eds.), O trabalho do psicólogo no Brasil (pp. 174-199). Porto Alegre, RS: Artmed.

Guimarães, S. B., Oliveira, I. F., \& Yamamoto, O. H. (2013). As práticas dos psicólogos em ambulatórios de saúde mental. Psicologia \& Sociedade, 25(3), 664-673. doi: 10.1590/S010271822013000300020

Leite, D. C., Andrade, A. B., \& Bosi, M. L. M. (2013). A inserção da Psicologia nos Núcleos de Apoio à Saúde da Família. Physis, 23(4), 1167-1187. doi: 10.1590/S0103-73312013000400008

Marcon, C., Luna, I. J., \& Lisbôa, M. L. (2004). O psicólogo nas instituições hospitalares: Características e desafios. Psicologia Ciência e Profissão, 24, 28-35. doi: 10.1590/S141498932004000100004

Oliveira, I. F., Amorim, K. M. O., Paiva, R. A., Oliveira, K. S. A., Nascimento, M. N. C., \& Belo, R. P. N. (2017). A atuação do psicólogo nos NASF: Desafios e perspectivas na atenção básica. Temas em Psicologia, 25, 291-304. doi: 10.9788/TP2017.1-17Pt 
Polejack, L., Gomes, P. M. G., Miranda, M. R. N. de, \& Machado, M. P. M. (2015). A psicologia na atenção básica: Descobertas, conquistas, considerações e desafios no NASF. In L. Polejack, A. M. A. Vaz, P. M. G. Gomes, \& V. C. Wichrowski (Eds.), Psicologia e politicas públicas na saúde - Experiências, reflexões, interfaces e desafios (pp. 97-125). Porto Alegre, RS: Rede Unida.

Polejack, L. P., Vaz, A. M. A., Gomes, P. M. G., \& Wichrowski, V. C. (Eds.). (2015). Psicologia e políticas públicas na saúde - Experiências, reflexões, interfaces e desafios. Porto Alegre, RS: Rede Unida.

Portaria $n^{\circ}$ 154, de 25 de janeiro de 2008. (2008). Cria os Núcleos de Apoio à Saúde da Família $N A S F$. Brasília, DF: Ministério da Saúde.

Resolução $n^{\circ}$ 5, de 15 de março de 2011. (2011). Institui as Diretrizes Curriculares Nacionais para os cursos de graduação em Psicologia, estabelecendo normas para o projeto pedagógico complementar para a Formação de Professores de Psicologia. Brasília, DF: Ministério da Educação.

Rousseau, D. M., \& Gunia, B. C. (2016). Evidence-based practice: The psychology of EBP implementation. Annual Review of Psychology, 26, 667-692. doi: 10.1146/annurev-psych-122414-033336

Rudnicki, T., \& Sanches, M. M. (Eds.). (2014). Psicologia da Saúde: A prática da terapia cognitivo-comportamental em hospital geral. Porto Alegre, RS: Sinopsys.

Seidl, E. M. F., \& Costa, A. L., Jr. (1999). O psicólogo na rede pública de saúde do Distrito Federal. Psicologia: Teoria e Pesquisa, 15(1), 27-35.

Seidl. E. M. F., \& Miyazaki, M. C. O. S. (Eds.). (2014). Psicologia da Saúde - Pesquisa e atuação profissional no contexto de enfermidades crônicas. Curitiba, PR: Juruá.
Spink, M. J. P., Bernardes, J., Santos, L., \& Gamba, E. A. C. (2007). A inserção de psicólogos em serviços de saúde vinculados ao SUS: Subsídios para entender os dilemas da prática e os desafios da formação profissional. In M. J. P. Spink (Ed.), A psicologia em diálogo com o SUS - Prática profissional e produção acadêmica (pp. 53-79). São Paulo, SP: Casa do Psicólogo.

Straub, R. (2014). Psicologia da saúde: Uma abordagem psicossocial. Porto Alegre, RS: Artmed.

Suls, J., \& Rothman, A. (2004). Evolution of the biopsychosocial model: Prospects and challenges for Health Psychology. Health Psychology, 23(2), 119-125. doi: 10.1037/02786133.23.2.119

Thielke, S., Thompson, A., \& Stuart, R. (2011). Health psychology in primary care: Recent research and future directions. Psychology Research and Behavior Management, 4, 59-58. doi: 10.2147/PRBM.S12996

Vinnuto, J. (2014). A amostragem em bola de neve na pesquisa qualitativa: Um debate em aberto. Temáticas (Campinas), 44, 203-220.

Yamamoto, O. H., Trindade, L. C. B. O., \& Oliveira, I. F. (2002). O psicólogo em hospitais no Rio Grande do Norte. Psicologia USP, 13(1), 217246. doi: 10.1590/S0103-65642002000100011

Received: 12/09/2017

$1^{\text {st }}$ revision: $10 / 05 / 2018$

Accepted: $14 / 05 / 2018$

(cc)BY (C) The Author(s), 2018. Open Access. This article is distributed under the terms of the Creative Commons Attribution 4.0 International License (http://creativecommons.org/licenses/by/4.0/), which permits unrestricted use, distribution, and reproduction in any medium, provided you give appropriate credit to the original author(s) and the source, provide a link to the Creative Commons license, and indicate if changes were made. 